\title{
Carbon Tetrachloride-Induced Hepatocellular Damage in Balb C Mice and Pharmacological Intervention by Extract of Daucus Carota
}

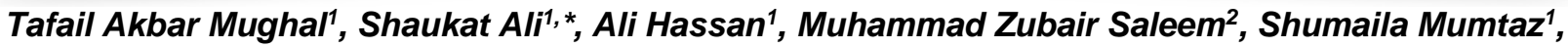 \\ Samaira Mumtaz ${ }^{1}$ \\ ${ }^{1}$ Medical Toxicology Laboratory, Department of Zoology, Government College University, Lahore, Pakistan. \\ ${ }^{2}$ College of Basic Medical Sciences, Dalian Medical University, Dalian Liaoning, China.
}

\begin{abstract}
Authors' Contributions
1 Conception \& Study Design, Data Collection

\& Processing, Data Analysis and/or

Interpretation.

2 Conception \& Study Design, Drafting of

Manuscript, Critical Review.

3 Data Collection \& Processing, Data Analysis and/or Interpretation.

4 Drafting of Manuscript, Critical Review.

5 Data Analysis and/or Interpretation, Drafting

of Manuscript.

6 Data Collection \& Processing, Critical

Review.
\end{abstract}

\begin{tabular}{l}
\hline Acknowledgement \\
The authors thank the Department of Zoology, \\
Government College University, Lahore, \\
Pakistan for providing all facilities for the \\
completion of this study. \\
\hline Article info. \\
Received: September 02, 2020 \\
Accepted: January 25, 2021 \\
Funding Source: Nil \\
Conflict of Interest: Nil \\
Cite this article: Mughal TA, Ali S, Hassan A, \\
Saleem MZ, Mumtaz S, Mumtaz S. Carbon \\
Tetrachloride-Induced Hepatocellular Damage \\
in Balb C Mice and Pharmacological \\
Intervention by Extract of Daucus Carota. \\
RADS J Pharm Pharm Sci. 2020; 8(4):200- \\
208. \\
*Address of Correspondence Author: \\
dr.shaukatali@gcu.edu.pk
\end{tabular}

dr.shaukatali@gcu.edu.pk

\author{
A B S TRACT \\ Background: Present research was planned to examine the shielding effect \\ of Daucus carota root extract pre-treatment on the carbon tetrachloride- \\ induced hepatotoxicity in Balb C mice.
}

Objective: To cover the assessment of the enzymatic activity such as Aspartate aminotransferase (AST), alanine aminotransferase (ALT) and lactate dehydrogenase (LDH) and biochemical constituents like cholesterol, protein, lipids, glucose and urea contents in both the blood and liver while RNA and DNA substances exclusively in the liver.

Setting: The induction of carbon tetrachloride $\left(\mathrm{CCl}_{4}\right)$-induced hepatotoxicity caused a rise in ALT of plasma and a decline in LDH.

Method: The mice were treated with $\mathrm{CCl}_{4}$ and Daucus carota extract to check their effect on the level of biochemical constituents.

Main Outcome Measure: Daucus carota extract pre-treatment obliterated $\mathrm{CCl}_{4}$-induced variations in the actions of enzymes.

Results: cholesterol content decreased while glucose level increased in the blood. Glucose, lipids, cholesterol and urea in the liver were reduced while total protein level rose. Daucus carota extract pre-treatment also prohibited $\mathrm{CCl}_{4}$-induced variations in total protein contents, urea, glucose and lipids in the liver. $\mathrm{CCl}_{4}$ action caused huge hepatic damage. This was averted by Daucus carota extract.

Conclusion: These outcomes reveal that Daucus carota root extract pretreatment inhibited hepatic damage induced by $\mathrm{CCl}_{4}$ in the mice model, which corroborates its defensive effects against hepatic damage produced by both non-oxidative and oxidative mechanisms.

Keywords: Hepatotoxicity, Carbon tetrachloride, Daucus carota root extract, Balb C mice, Pre-treatment. 


\section{INTRODUCTION}

The liver is the major detoxifying organ present in our body [1] that's why most of the toxicological problems are related to it [2]. Liver cells are harmed by oxidative damage through hepatotoxicants [3].

Carbon tetrachloride a xenobiotic liberated in water from numerous industries and causes hepatotoxicity in animals exposed to it [4]. Production of free radicals also takes place during normal physiological courses [5] but, when the balance between free radical scavenging and reactive oxygen species (ROS) is disturbed, it leads to tissue damage and necrosis [6]. $\mathrm{CCl}_{4}$ is an eminent hepatotoxin widely used in experimental animals to test liver damage. The basic causes behind $\mathrm{CCl}_{4}$-induced hepatic damage are free radical generation, reduced antioxidant enzyme activity and lipid peroxidation [79]. Hepatotoxins bout on the fatty acids of cell membranes which causes a rise of lipid peroxides which lose functional integrity of liver mitochondria leading to hepatic damage [10]. Hepatopathies are treated by producing an antioxidant effect or by the lessening of free radicals production [11]. Synthetic and as well as natural drugs are obtainable for the cure of liver-related diseases [12] but plant-based medicines got the utmost importance against druginduced hepatotoxicity [13]. Therefore plant-based medicines, rich in antioxidants, are the need of the period due to toxicity problems related to certain drugs [14,15]. In this regard, many plants are used to treat liver diseases. Present research deals with the study of the antioxidant potential of Daucus carota.

\section{AIM OF THE STUDY}

The goal of the experiment was to cover the assessment of the enzymatic activity such as alanine aminotransferase (ALT) and lactate dehydrogenase (LDH) and aspartate aminotransferase (AST) and biochemical constituents like protein contents, cholesterol, urea, glucose and lipids in both the blood and liver while RNA and DNA contents only in the liver.

\section{Ethical Approval}

Animal trials were directed in accord with indigenous (law of Government College University, Lahore, Pakistan) and international law (Wet op de dierproeven, Wod, Article 9 of Dutch Law). This article was written without any experimentation on human beings.

\section{MATERIALS AND METHODS}

\section{Preparations of the Aqueous Extract of Daucus Carota Root}

The Daucus carota root was acquired from the local market and carried to the department of botany for confirmation. The roots were freed of superfluous materials, dried in the shade at room temperature, and ground into a uniform powder. $20 \mathrm{~g}$ of the powder was added to a $250 \mathrm{ml}$ conical flask which contains $150 \mathrm{ml}$ distilled water. The solution was stirred and allowed to soak for $24 \mathrm{hrs}$. The plant extract was filtered through cotton wool implanted in a glass funnel. Then the filtrate was filtered through filter paper again. The filtrate was concentrated by evaporation and poured into a $100 \mathrm{ml}$ flask.

\section{Chemical Used}

Carbon tetrachloride was obtained from Sigma, Aldrich (USA).

\section{Experimental Animals and Dose Preparation}

Twenty-four Balb C mice were acquired having an average weight of $50 \mathrm{~g}$ from GC University Lahore, Pakistan. The mice were treated kindly, kept in cages placed in the aired and hygienic animal house under proper settings of temperature and wetness. Mice were kept in an animal house at $20^{\circ} \mathrm{C} \pm 2^{\circ} \mathrm{C}$ and exposed to ordinary photoperiod of $12 \mathrm{hrs}$ dark and $12 \mathrm{hrs}$ light cycle. The purified drinking water and standard laboratory pellet feed were provided to animals ad libitum. The lethal dose (LD50) of $\mathrm{CCl}_{4}$ was taken as $1 \mathrm{ml} / \mathrm{kg} \mathrm{b}$. w. The mice were distributed into four groups of six mice each namely I, II, III and IV. The Control group was Group I. Group II was provided with Daucus carota extract $(100 \mathrm{mg} / \mathrm{kg}$ body weight), Group III was administered with $\mathrm{CCl}_{4}(0.4$ $\mathrm{ml} / \mathrm{kg}$ b. w) and Group IV was provided with Daucus carota extract plus $\mathrm{CCl}_{4}(0.4 \mathrm{ml} / \mathrm{kg}$ body weight). The injections were administered intra-peritoneal. Animals were anesthetized after $24 \mathrm{~h}$ of the last dosing, dissected and blood was collected. Blood was saved in heparinized $(20 \mu \mathrm{l}$ heparin/ $1 \mathrm{ml}$ of blood) tubes and was centrifuged at $3000 \mathrm{rpm}$ for $30 \mathrm{mins}$ for the isolation of plasma for the assessment of biochemical components and enzymatic activities. The liver was separated from the body and divided into two portions, one for preparation of total nucleic 
acid, cholesterol, protein, lipids extract and the other for saline extraction (See Figure 1).

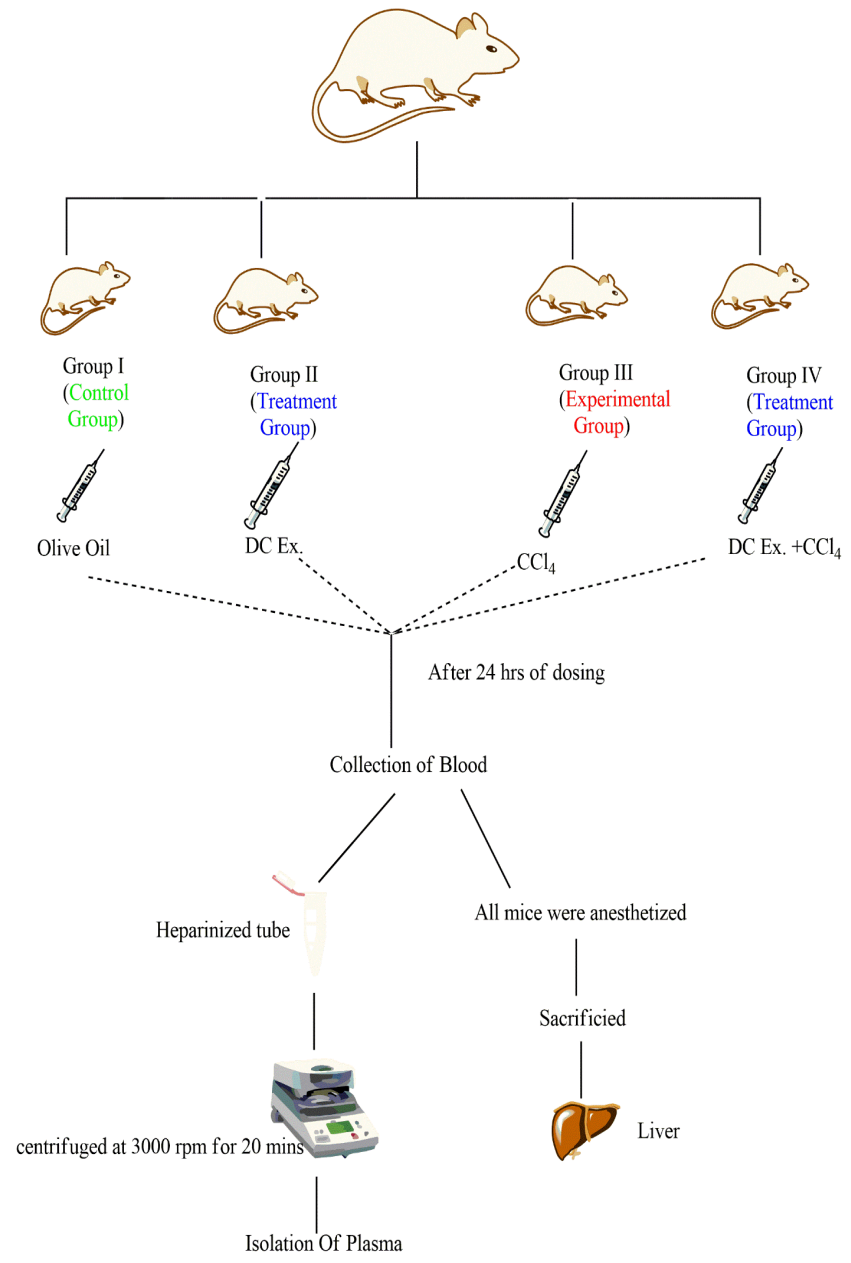

Figure 1. A scheme showing grouping, treatment, biochemical and hepatic analysis of animals.

For the valuation of activities of LDH, AST, ALT and hepatic soluble proteins, urea and glucose, $5 \mathrm{ml}$ of $0.9 \%$ saline solution was used to homogenize the 250 mg liver part.

\section{Lipids, Nucleic Acid and Protein Extraction}

A separate part of the liver was pulverized in boiling ethanol and allowed to centrifuge at $3000 \mathrm{rpm}$ for 20 minutes for obtaining lipids, nucleic acid and proteins. The supernatant was stored in another tube and normal ethanol was mixed with pellet for the second time. It was centrifuged at $3000 \mathrm{rpm}$ after being kept overnight. After the collection of supernatant from the upper portion, a mixture of methanol and ether (3:1) was used to mix the pellet. After preserving it for $24 \mathrm{~h}$, this was again centrifuged at $3000 \mathrm{rpm}$ for 20 mins. The estimation of total lipids and cholesterol contents was done with the already mixed supernatant. The pellet was dried for $24 \mathrm{~h}$ in vacuum desiccators after the extraction of lipid. Nucleic acid and protein contents were extracted and estimated by a method mentioned by Mughal et al. [16].

\section{Estimation of Biochemical Components in Liver and Plasma}

The level of glucose, total lipids, cholesterol, urea, total protein, soluble protein, AST, ALT and LDH in plasma and the saline extract and DNA and RNA only in the saline extract were estimated by the method described by Mughal et al. [16].

\section{Statistical Analysis}

All data was stated as mean $\pm S E M$. To calculate variances among the studied groups, statistical analysis was done using the one-way analysis of variance (ANOVA). The significant value was taken as $\mathrm{P}<0.05$.

\section{RESULTS}

\section{Effects on Biochemical Components \\ Effects on Liver \\ Effect on Total Lipid}

High significant reduction in total lipid level $\left(\mathrm{CCl}_{4}\right.$ : $47.2 \pm 2.7 \mathrm{mg} / \mathrm{g}$ ) as compared to control $(64.8 \pm 2.3$ $\mathrm{mg} / \mathrm{g})$ was caused by the $\mathrm{CCl}_{4}(0.4 \mathrm{ml} / \mathrm{kg})$ Intraperitoneal administration. When the combination of Daucus carota extract and $\mathrm{CCl}_{4}$ was given it resulted in a significant rise in the total lipid level $(65.0 \pm 1.5 \mathrm{mg} / \mathrm{g})$ in comparison to the $\mathrm{CCl}_{4}$ treated group (Figure 2).

\section{Effect on Urea}

A highly significant reduction in urea level ( $\mathrm{CCl} 4$ : $5.8 \pm 0.3 \mathrm{mg} / \mathrm{g})$ as compared to control $(14.8 \pm 1.5$ $\mathrm{mg} / \mathrm{g}$ ) was caused by $\mathrm{CCl}_{4}$ intraperitoneal administration. When the combination of Daucus carota extract and $\mathrm{CCl}_{4}$ was given, it produced a highly significant rise in its level $(10.5 \pm 0.9 \mathrm{mg} / \mathrm{g})$ as compared to $\mathrm{CCl}_{4}$ (Figure 2).

\section{Effect on Glucose}

A high significant drop in glucose level in comparison to control (control: $6.3 \pm 1.1 \mathrm{mg} / \mathrm{g}, \mathrm{CCl}_{4}: 1.1 \pm 0.1 \mathrm{mg} / \mathrm{g}$ ) was caused by $\mathrm{CCl}_{4}$ Intraperitoneal administration. When the combination of Daucus carota extract and $\mathrm{CCl}_{4}$ was given, it caused a highly significant increase $(6.0 \pm 0.7 \mathrm{mg} / \mathrm{g})$ in its level as compared to $\mathrm{CCl}_{4}$. (Figure 2). 

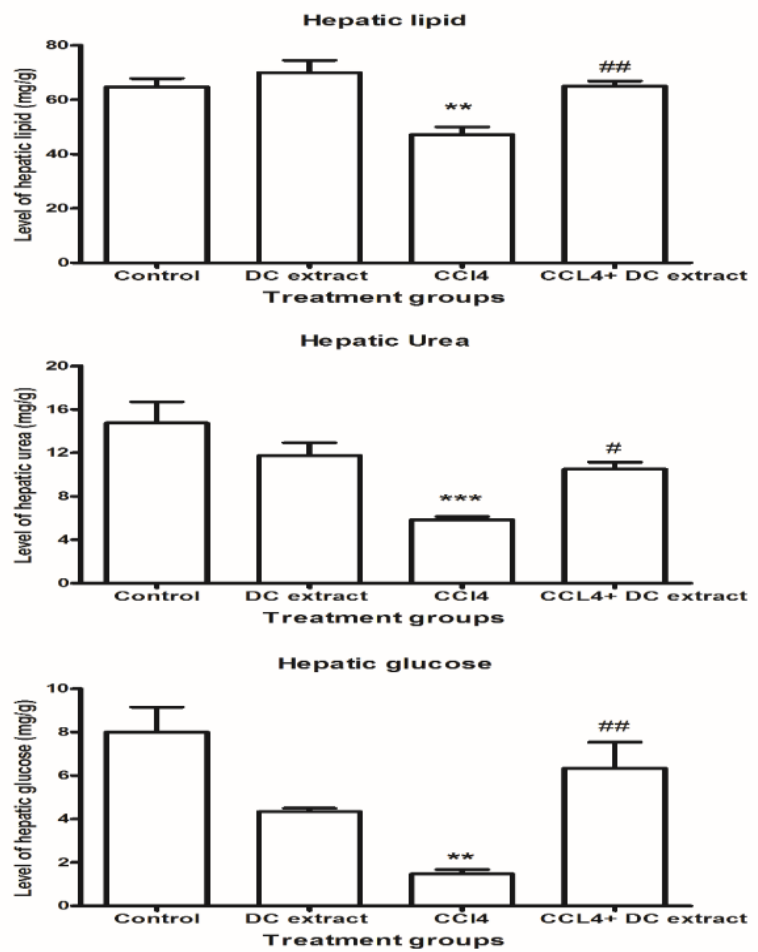

Figure 2. Assessment of biochemical components (lipid, urea and glucose) in the liver of Balb C mice.

$\left(^{*}\right)$ indicates the significant difference between control and $\mathrm{CCl}_{4}$. (\#) indicates significant difference between $\mathrm{CCl}_{4}$ and $\mathrm{CCl}_{4}+\mathrm{DC}$ extract. Each bar represents the mean value of six replicates and SEM. Statistical icons: $\#=p \leq 0.05,{ }^{* *}, \# \#=p \leq 0.01,{ }^{* * *},=p \leq 0.001$

\section{Effect on Cholesterol}

A highly significant drop in cholesterol level $(6.3 \pm 0.4$ $\mathrm{mg} / \mathrm{g})$ as juxtaposed to control $(10.25 \pm 0.64 \mathrm{mg} / \mathrm{g})$ was caused by $\mathrm{CCl}_{4}$ Intraperitoneal administration. When the combination of Daucus carota extract and $\mathrm{CCl}_{4}$ was given, it caused no significant rise in its level as compared to $\mathrm{CCl}_{4}$. Figure 3.

\section{Effect on Total Protein}

Intraperitoneal delivery of $\mathrm{CCl}_{4}$ resulted in a significant rise in total protein level $(185.0 \pm 1.9 \mathrm{mg} / \mathrm{g})$ as compared to control $(164.0 \pm 4.1 \mathrm{mg} / \mathrm{g})$. When the combination of Daucus carota extract and $\mathrm{CCl}_{4}$ was given, it resulted in a highly significant reduction in its level $(157.0 \pm 3.4 \mathrm{mg} / \mathrm{g})$ when matched to $\mathrm{CCl}_{4}$.

Figure 3.

\section{Effect on Soluble Protein}

Intraperitoneal delivery of $\mathrm{CCl}_{4}$ instigated a significant rise in soluble protein level $(79.8 \pm 1.5 \mathrm{mg} / \mathrm{g})$ as compared to control $(50.5 \pm 1.5 \mathrm{mg} / \mathrm{g})$. When the combination of Daucus carota extract and $\mathrm{CCl}_{4}$ was given, it resulted in a highly significant drop in soluble protein level $(59.5 \pm 0.95 \mathrm{mg} / \mathrm{g})$ as compared to $\mathrm{CCl}_{4}$. Figure 3.
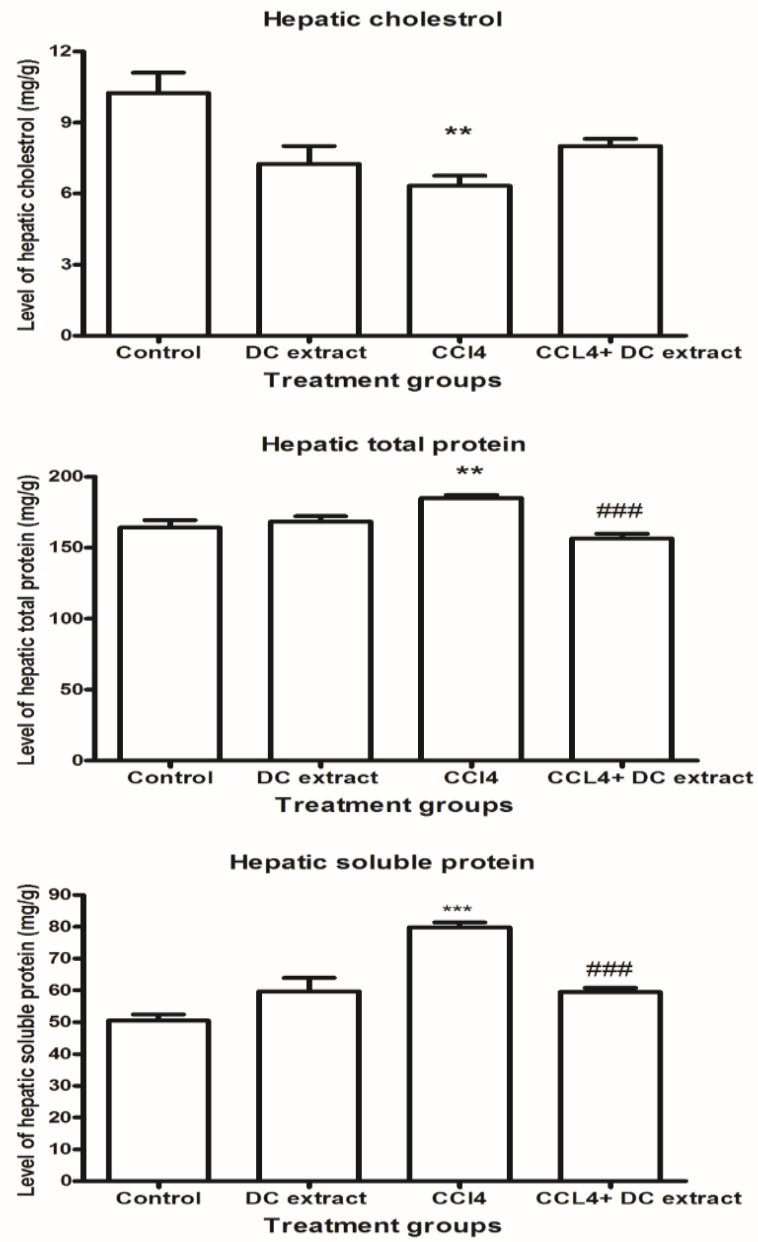

Figure 3. Assessment of biochemical components (cholesterol, total protein and soluble protein) in the liver of Balb C mice.

\section{Effect on DNA}

Intraperitoneal organization of $\mathrm{CCl}_{4}$ resulted in a significant decline in DNA level $(6.2 \pm 0.9 \mathrm{mg} / \mathrm{g})$ as compared to control $(10.0 \pm 0.6 \mathrm{mg} / \mathrm{g})$. When Daucus carota extract was given with $\mathrm{CCl}_{4}$ it resulted in a significant rise in its level $(9.2 \pm 0.3 \mathrm{mg} / \mathrm{g})$ as compared to $\mathrm{CCl}_{4}$. Figure 4.

\section{Effect on RNA}

$\mathrm{CCl}_{4}$ intraperitoneal administration resulted in a highly significant decrease in hepatic RNA level (5.5 \pm 0.6 $\mathrm{mg} / \mathrm{g})$ as compared to control $(11 \pm 0.8 \mathrm{mg} / \mathrm{g})$ was observed by $\mathrm{CCl}_{4}$ Intraperitoneal administration. When the combination of Daucus carota extract and $\mathrm{CCl}_{4}$ was given, it resulted in a significant rise in its level $(9.5 \pm 0.7 \mathrm{mg} / \mathrm{g})$ as compared to $\mathrm{CCl}_{4}$. Figure 4 . 

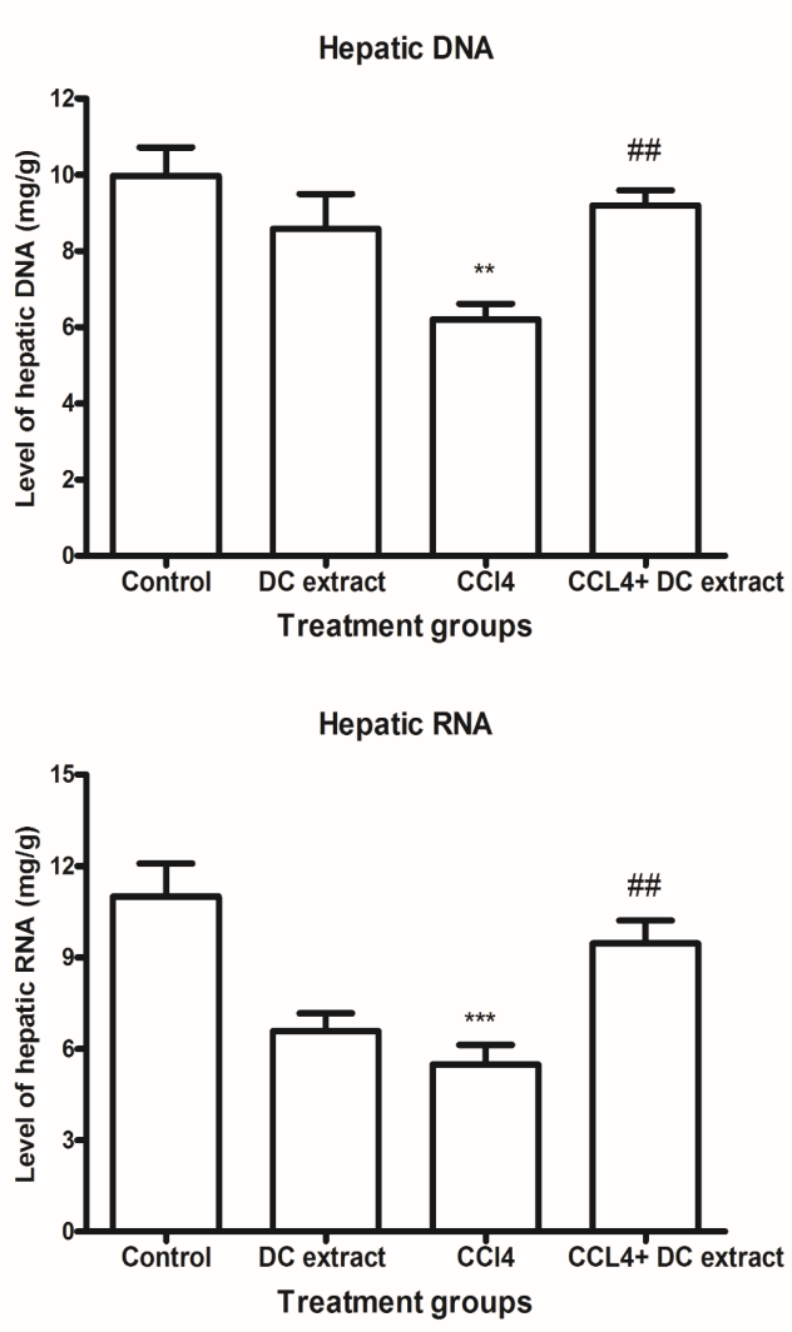

Figure 4. Assessment of biochemical components (DNA and RNA) in the liver of Balb C mice.

Each bar signifies the mean value of six replicates and SEM. Statistical icons: ${ }^{* *}, \# \#=p \leq 0.01,{ }^{* * *}=p \leq$ 0.001 .

\section{Effects on Enzymatic Activities}

$\mathrm{CCl}_{4}$ intraperitoneal administration and $\mathrm{CCl}_{4}+$ Daucus carota extract mixture produced no significant change in AST and ALT. ALT (control: $0.17 \pm 0.038 \mathrm{IU} / \mathrm{g}, \mathrm{CCl}_{4}$ : $0.06 \pm 0.01 \mathrm{IU} / \mathrm{g}$, Daucus carota extract: $0.097 \pm 0.002$ $\mathrm{IU} / \mathrm{g}$, Daucus carota extract $+\mathrm{CCl}_{4}: 0.005 \pm 0.004$ $\mathrm{IU} / \mathrm{g}$ ), AST (control: $38.15 \pm 4.53 \mathrm{IU} / \mathrm{g}, \quad \mathrm{CCl}_{4}$ : $27.83 \pm 6.13 \mathrm{IU} / \mathrm{g}$, Daucus carota extract: $42.25 \pm 2.23$ $\mathrm{IU} / \mathrm{g}$, Daucus carota extract $+\mathrm{CCl}_{4}: 31.5 \pm 2.9 \mathrm{IU} / \mathrm{g}$ ). $\mathrm{CCl}_{4}$ intraperitoneal administration produced no significant variation in LDH level $(1.96 \pm 0.06 \mathrm{IU} / \mathrm{g})$ as matched to control $(1.99 \pm 0.22 \mathrm{IU} / \mathrm{g})$ and caused a highly significant decrease $(0.88 \pm 0.02 \mathrm{IU} / \mathrm{g})$ when $\mathrm{CCl}_{4}$ was given in combination with Daucus carota extract Figure $\mathbf{5}$.
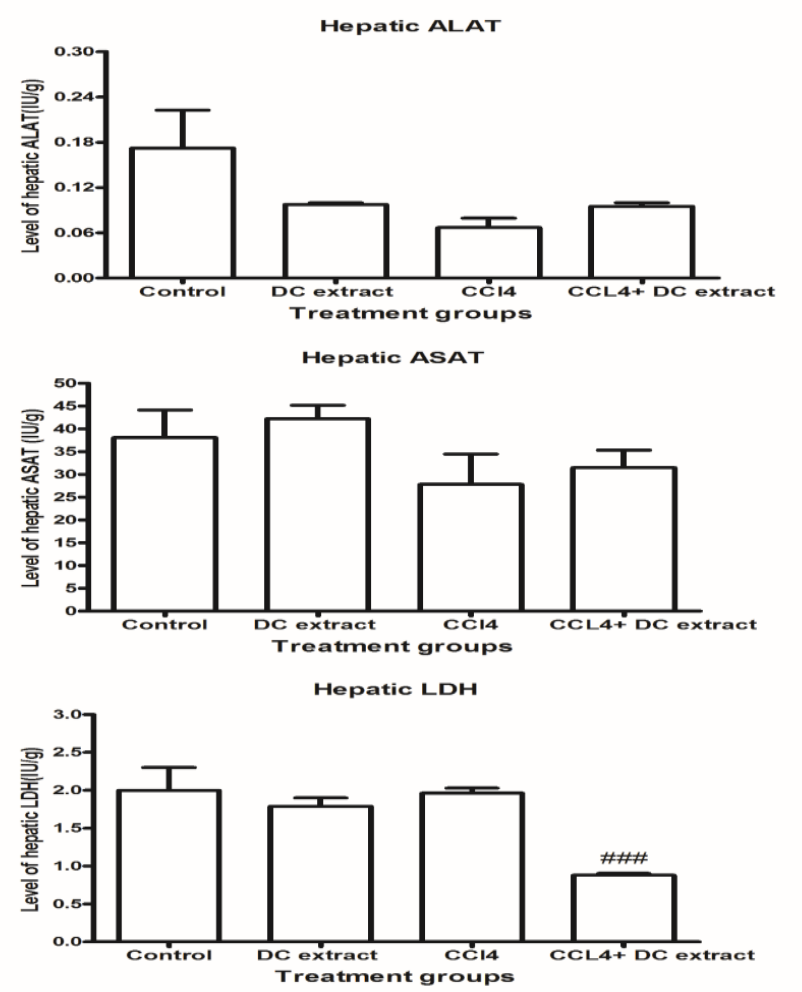

Figure 5. Analysis of enzymes (ALT, AST and LDH) in the liver of Balb $\mathrm{C}$ mice.

Each bar embodies the mean value of six replicates and SEM. Statistical icon: \#\#= $p \leq 0.001$.

\section{Effects on Blood}

\section{Effects on Biochemical Components}

\section{Effect on Total Lipids}

$\mathrm{CCl}_{4}$ intraperitoneal administration produced no significant variation $(240.8 \pm 42.4 \mathrm{mg} / 100 \mathrm{ml})$ as compared to control $(215.3 \pm 31.9 \mathrm{mg} / 100 \mathrm{ml})$. When Daucus carota extract $+\mathrm{CCl}_{4}$ were given in combination it again showed no significant change $(200.0 \pm 5.3 \mathrm{mg} / 100 \mathrm{ml})$. Figure 6 .

\section{Effect on Urea}

$\mathrm{CCl}_{4}$ intraperitoneal administration produced no significant change in urea level $(29.7 \pm 2.5 \mathrm{mg} / 100 \mathrm{ml})$ as compared to control $(35.3 \pm 3.5 \mathrm{mg} / 100 \mathrm{ml})$. When the combinations of Daucus carota extract and $\mathrm{CCl}_{4}$ was given, it resulted in a highly significant rise in its level $(45.6 \pm 1.5 \mathrm{mg} / 100 \mathrm{ml})$ as compared to $\mathrm{CCl}_{4}$. Figure 6.

\section{Effect on Glucose}

$\mathrm{CCl}_{4}$ intraperitoneal administration produced an extremely significant rise in the level of glucose $(214.0 \pm 18 \mathrm{mg} / 100 \mathrm{ml})$ as compared to control $(85.0 \pm 4.6 \mathrm{mg} / 100 \mathrm{ml})$. When Daucus carota extract 
was given with $\mathrm{CCl}_{4}$ it caused a significant decline $(138.0 \pm 14.8 \mathrm{mg} / 100 \mathrm{ml})$ in its level as compared to $\mathrm{CCl}_{4}$. Figure 6.
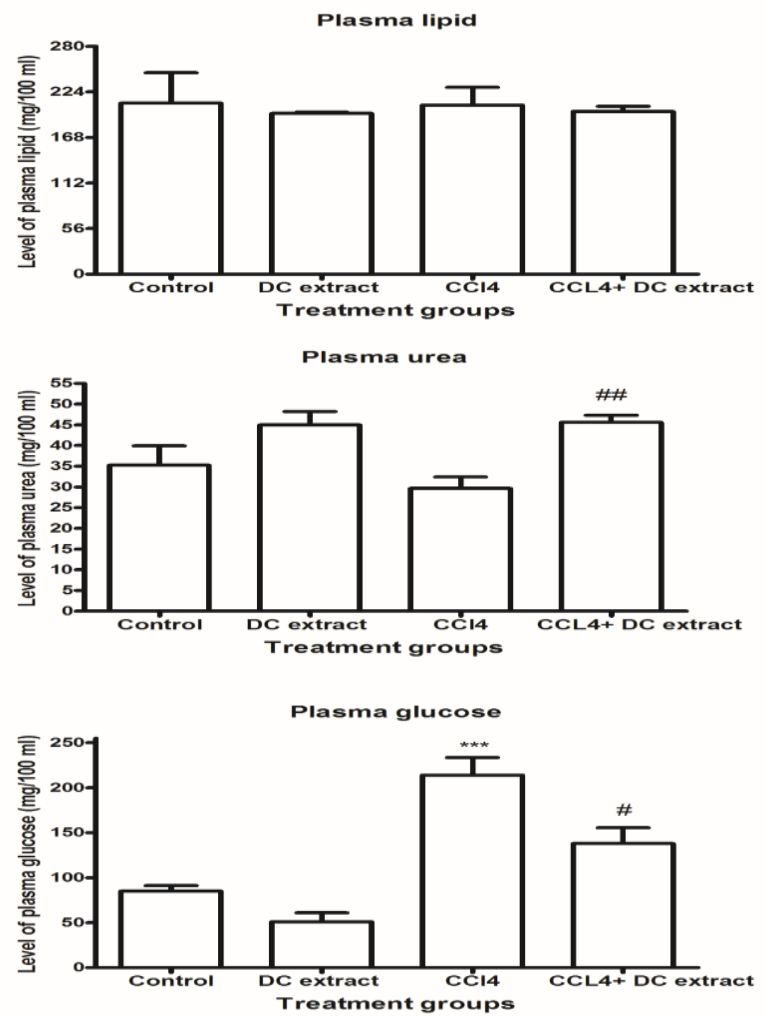

Figure 6. Assessment of biochemical components (lipid, urea and glucose) in plasma of Balb $\mathrm{C}$ mice

Each bar embodies the mean value of six replicates and SEM. \#= p $\leq 0.05, \#=p \leq 0.01,{ }^{* * *},=p \leq 0.001$.

\section{Effect on Cholesterol}

$\mathrm{CCl}_{4}$ intraperitoneal administration produced a highly significant drop in cholesterol level (150.3 \pm 16.1 $\mathrm{mg} / 100 \mathrm{ml})$ as compared to control $(309.0 \pm 31.30$ $\mathrm{mg} / 100 \mathrm{ml}$ ). When the combination of $\mathrm{CCl}_{4}$ and Daucus carota extract was given, it produced no significant variation in its level $(124.8 \pm 6.7 \mathrm{mg} / 100 \mathrm{ml})$ as compared to $\mathrm{CCl}_{4}$. Figure 7 .

\section{Effect on Cholesterol}

$\mathrm{CCl}_{4}$ intraperitoneal administration and $\mathrm{CCl}_{4}+$ Daucus carota extract produced no significant variation in total protein level in comparison to control (control: $4107.8 \pm 204.9 \mathrm{mg} / 100 \mathrm{ml}, \mathrm{CCl}_{4}: 3970.2 \pm 158 \mathrm{mg} / 100$ $\mathrm{ml}$, Daucus carota extract $+\mathrm{CCl}_{4}: 4631.8 \pm 238.8$ $\mathrm{mg} / 100 \mathrm{ml})$. Figure 7.

\section{Effect on Total Protein}

$\mathrm{CCl}_{4}$ intraperitoneal administration and $\mathrm{CCl}_{4}+$ Daucus carota extract produced no significant variation in total protein level in comparison to control (control:
$4107.8 \pm 204.9 \mathrm{mg} / 100 \mathrm{ml}, \mathrm{CCl}_{4}: 3970.2 \pm 158 \mathrm{mg} / 100$ $\mathrm{ml}$, Daucus carota extract $+\mathrm{CCl}_{4}: 4631.8 \pm 238.8$ $\mathrm{mg} / 100 \mathrm{ml}$ ). Figure 7.
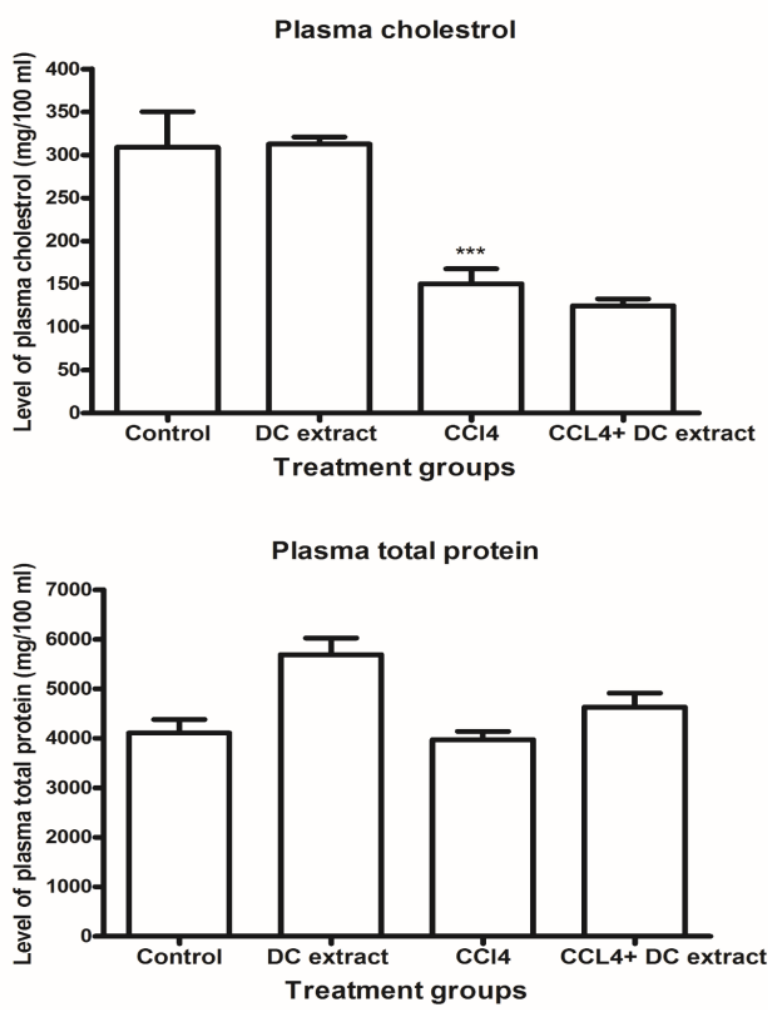

Figure 7. Assessment of biochemical components (cholesterol and total protein) in plasma of Balb $\mathrm{C}$ mice

Each bar signifies the mean value of six replicates and SEM. ${ }^{* *},=p \leq 0.001$.

\section{Effects on Enzymatic Activities}

\section{Effect on ALT}

Intraperitoneal delivery of $\mathrm{CCl}_{4}$ produced a vastly significant rise in the level of ALT $(597.8 \pm 66.2 \mathrm{mg} / 100$ $\mathrm{ml}$ ) as compared to control $(99.7 \pm 13.8 \mathrm{mg} / 100 \mathrm{ml})$. When the combination of $\mathrm{CCl}_{4}$ and Daucus carota extract was given it resulted in a highly significant reduction in its level $(55 \pm 3.3 \mathrm{mg} / 100 \mathrm{ml})$ as compared to $\mathrm{CCl}_{4}$. Figure 8.

\section{Effect on AST}

Intraperitoneal delivery of $\mathrm{CCl}_{4}$ resulted in no significant alteration in the AST level $(452.5 \pm 56.2$ $\mathrm{mg} / 100 \mathrm{ml})$ as compared to control $(293.8 \pm 15.7$ $\mathrm{mg} / 100 \mathrm{ml}$ ). When the combination of $\mathrm{CCl}_{4}$ and Daucus carota extract was given, it resulted in a highly significant reduction in its level $(212.6 \pm 19.4$ $\mathrm{mg} / 100 \mathrm{ml})$ as compared to $\mathrm{CCl}_{4}(452.5 \pm 56.2 \mathrm{mg} / 100$ $\mathrm{ml}$. Figure 8. 


\section{Effect on LDH}

$\mathrm{CCl}_{4}$ intraperitoneal administration produced a highly significant decline in the level of Plasma LDH $(2.0 \pm 0$ $\mathrm{mg} / 100 \mathrm{ml})$ as compared to control $(87.3 \pm 3.5 \mathrm{mg} / 100$ $\mathrm{ml}$ ). When Daucus carota extract $+\mathrm{CCl}_{4}$ were given in combination a significant increase in its level $(22.2 \pm 1.7 \mathrm{mg} / 100 \mathrm{ml})$ was seen as compared to $\mathrm{CCl}_{4}$. Figure 8.
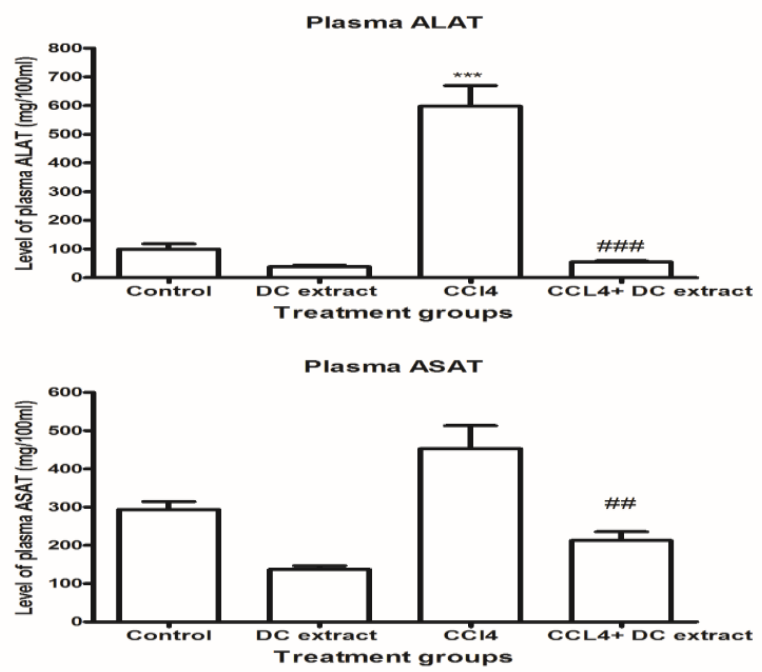

Plasma LDH

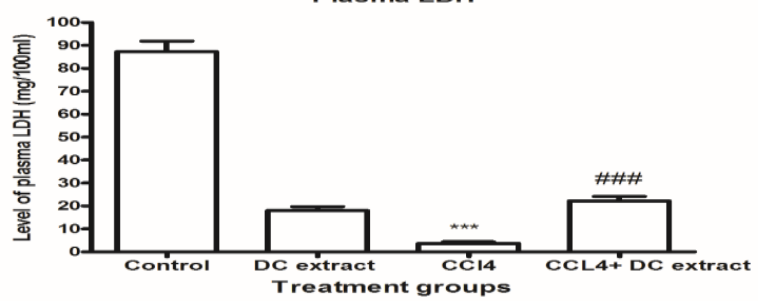

Figure 8 Analysis of enzymes (ALT, AST and LDH) in plasma of Balb $\mathrm{C}$ mice

Each bar denotes the mean value of six replicates and SEM. \#\# = p $\leq 0.01,{ }^{* * *}, \# \#=p \leq 0.001$.

\section{DISCUSSION}

$\mathrm{CCl}_{4}$ is used as a dry cleaning agent, refrigerant and, solvent for oils and fats. Its inhalation causes damage to the kidneys and liver. $\mathrm{CCl}_{4}$ is also a human carcinogen [17]. The major detoxifying organ present in our body is the liver [1] that's why most of the toxicological problems are associated with it [2]. Liver cells are harmed by oxidative damage through hepatotoxicants [3]. This indicates the necessity of studying the hepatotoxicity induced by $\mathrm{CCl}_{4}$ and possible preventive opportunities.

$\mathrm{CCl}_{4}$ intraperitoneal administration produced a highly significant drop in hepatic total Urea, lipid, cholesterol and glucose level whereas a highly significant surge in total proteins was related to control. The same pattern was in the study of Benahmed et al. [18]. When the combination of $\mathrm{CCl}_{4}$ and Daucus carota extract was given, it abolished all the changes significantly except cholesterol contents which remained significantly unchanged in comparison to $\mathrm{CCl}_{4}$ treated group. Increased consumption of glucose could be resulted in hepatic glucose contents reduction due to $\mathrm{CCl}_{4}$ administration during toxic insult [19]. Toxic constituents are exposed to P-450 metabolism (Phase I biotransformation). The products of phase I then conjugate with the phase II enzymes. Glucoronidase and similar conjugates are eliminated from the body.

This use of glucose in process of glucuronidation may have resulted in a low level of glucose. The energy produced from glucose also helps to battle toxins produced in stress conditions. Increased level of protein contents while the decreased level of hepatic cholesterol, glucose, total lipids and urea has also been observed in Wister Albino rats [20] and Balb C mice after $\mathrm{CCl}_{4}$ treatment [16]. Pre-treatment of Daucus carota extract prohibited $\mathrm{CCl}_{4}$ induced variations in cholesterol, lipids and glucose contents to some level. The increased level of protein production during the regeneration of damaged tissues could have resulted in this increase in total protein. Loss of functioning of liver tissue might be the reason for the decreased level of hepatic urea contents.

Administration of $\mathrm{CCl}_{4}$ single dose to Balb $\mathrm{C}$ mice produced an extremely significant rise in ALT level of plasma, very significant decline in LDH level of Plasma though no significant alteration in AST level of Plasma in comparison to control and Daucus carota extract. When the combination of $\mathrm{CCl}_{4}$ and Daucus carota extract was given, it caused a highly significant fall in the level of ALT and a highly significant surge in $\mathrm{LDH}$ level in comparison to $\mathrm{CCl}_{4}$. An increase in plasma $\mathrm{LDH}, \mathrm{AST}$ and ALT were also observed in rats [21] and Balb C mice [16] after $\mathrm{CCl}_{4}$ administration. Also in the previous experiment conducted by Zhang et al. [22] the rise in ALT and AST level was observed. Treatment with glucagonlike peptide-1 analogue liraglutide resulted in decrease in the level of ALT and AST. Administration of $\mathrm{CCl}_{4}$ in rats for $24 \mathrm{~h}$ induced surge in plasma ALT and AST activities, exhausted sulfhydryl contents, reduced total antioxidant abilities, induced 
genotoxicity and major liver lipid peroxidation. $\mathrm{CCl}_{4}$ raises AST and ALT levels along with lipid peroxidative enzymes, for example, catalase and superoxide dismutase in the liver [23]. These may indicate injury to the liver tissues caused the escape of these enzymes into the blood. A vastly significant fall in cholesterol contents and rise in the glucose of plasma lwas detected after administration of $\mathrm{CCl}_{4}$. When the combination of $\mathrm{CCl}_{4}$ and Daucus carota extract was given, it resulted in a highly significant rise in cholesterol contents and a highly significant decline in the level of glucose as matched to $\mathrm{CCl}_{4}$. The liver injury could have resulted in a reduced level of cholesterol because the liver crops $80 \%$ cholesterol in the body [24]. $\mathrm{CCl}_{4}$ induction caused an extremely significant drop in urea level of plasma while total proteins of plasma and total lipids level showed no significant change. Daucus carota extract pretreatment eliminated the variations in plasma contents of urea. These results were in agreement with the study of Afzal et al. [25] Daucus carota extracts in petroleum ether solvent reduced the serum urea, uric acid and creatinine. A decreased level of plasma urea may represent liver injury as the production of urea is the purpose of the liver through amelioration of these substances by Daucus carota extract pre-treatment prove its hepatic protective effects. Kula et al. [26] isolated the bioactive compounds present in Daucus carota. The oils were dominated by monoterpene hydrocarbons (66-85\%) and myrcene (12-24\%). The most abundant sesquiterpene constituents were $\beta$-caryrophyllene $(4.6-13.2 \%)$ and carotol. These components might be responsible for its role in protection of liver effect. Shebaby et al. [27] reported that Daucus carota extract are composed of $\beta$-himachalene, $\alpha$-selinene, $\beta$-selinene, $\beta$-caryophyllene, $\alpha$-humelene, $\gamma$-selinene, $\alpha$-longipinene. The F2 fraction was markedly dominated by the sesquiterpene 2-himachalen-6-ol and noticeable amounts of three phenylpropanoids:elemicin, (E)-methyl isoeugenol, and methyl eugenol. The results of their study showed that Daucus carota extract is effective in $\mathrm{CCl}_{4}$ induced hepatotoxicity.

\section{CONCLUSION}

It was determined that $\mathrm{CCl}_{4}$ at a given dose in mice is a potential hepatotoxicant. Daucus carota extract can stop the injury produced by $\mathrm{CCl}_{4}$.

\section{Conflicts of interest}

All authors declare there are no conflicts of interest.

\section{REFERENCES}

1. Rane J, Jadhao R, Bakal R. Liver diseases and herbal drugs: A review. J Innov Pharm Biol Sci. 2016;3(2):24-36.

2. Ramappa V, Aithal GP. Hepatotoxicity related to anti-tuberculosis drugs: mechanisms and management. J Clin Exp Hepatol. 2013;3(1):3749. https://doi.org/10.1016/j.jceh.2012.12.001.

3. Singh D, Cho WC, Upadhyay G. Drug-induced liver toxicity and prevention by herbal antioxidants: an overview. Front Physiol. 2016;6:363. https://doi.org/10.3389/fphys.2015.00363.

4. Acharya K, Chatterjee S, Biswas G, Chatterjee A, Saha GK. Hepatoprotective effect of a wild edible mushroom on carbon tetrachloride-induced hepatotoxicity in mice. Int $\mathrm{J}$ Pharm Pharm Sci. 2012;4(3):285-88.

5. Phaniendra A, Jestadi DB, Periyasamy L. Free radicals: properties, sources, targets, and their implication in various diseases. Ndian J Clin Biochem. $\quad 2015 ; 30 \quad$ (1):11-26. https://doi.org/10.1007/s12291-014-0446-0.

6. Nita M, Grzybowski A. The role of the reactive oxygen species and oxidative stress in the pathomechanism of the age-related ocular diseases and other pathologies of the anterior and posterior eye segments in adults. Oxid Med Cell Longev. $\quad 2016 ;: \quad$ Article ID 3164734. https://doi.org/10.1155/2016/3164734.

7. Dutta S, Chakraborty AK, Dey P, Kar P, Guha P, Sen S, Chaudhuri TK. Amelioration of $\mathrm{CCl}_{4}$ induced liver injury in swiss albino mice by antioxidant rich leaf extract of Croton bonplandianus Baill. PloS one. 2018;13(4):e0196411.

8. Ighodaro OM, Akinloye OA. Sapium ellipticum (Hochst) Pax leaf extract: antioxidant potential in $\mathrm{CCl}_{4}$-induced oxidative stress model. Bull Fac Pharm Cairo Univ. 2018;56 (1):54-59. https://doi.org/10.1016/j.bfopcu.2017.11.001.

9. Lu Y, Chen J, Ren D, Yang X, Zhao Y. Hepatoprotective effects of phloretin against $\mathrm{CCl}_{4-}$ induced liver injury in mice. Food Agric Immunol. 2017;28(2):211-22. https://doi.org/10.1080/09540105.2016.1258546

10. Akhtar MS, Asjad HMM, Bashir S. Evaluation of antioxidant and hepatoprotective effects of Khamira Gaozaban Ambri Jadwar Ood Saleeb Wala (KGA). Bangladesh J Pharmacol. 2013;8(44):13183. DOI: 10.3329/bjp.v8i1.13183. 
11. Al-Dbass AM, Al-Daihan SK, Bhat RS. Agaricus blazei Murill as an efficient hepatoprotective and antioxidant agent against $\mathrm{CCl}_{4}$-induced liver injury in rats. Saudi J Biol Sci. 2012;19(3):303-09. https://doi.org/10.1016/j.sjbs.2012.03.004.

12. Hong M, Li S, Tan HY, Wang N, Tsao S-W. Current status of herbal medicines in chronic liver disease therapy: the biological effects, molecular targets and future prospects. Int $\mathrm{J}$ Mol Sci. 2015;16(12):28705-745. https://doi.org/10.3390/ijms161226126.

13. Xiong F, Guan Y-S. Cautiously using natural medicine to treat liver problems. World $\mathrm{J}$ Gastroenterol. 2017;23(19):3388-95. doi: 10.3748/wjg.v23.i19.3388.

14. Chao J, Liao J-W, Peng W-H, Lee M-S, Pao L-H, Cheng H-Y. Antioxidant, analgesic, antiinflammatory, and hepatoprotective effects of the ethanol extract of Mahonia oiwakensis stem. Int J Mol Sci. 2013;14(2):2928-45. https://doi.org/10.3390/ijms14022928.

15. Alok S, Jain SK, Verma A, Kumar M, Mahor A, Sabharwal M. Herbal antioxidant in clinical practice: a review. Asian Pac J Trop Biomed. 2014;4(1):78-84. https://doi.org/10.1016/S22211691(14)60213-6.

16. Mughal TA, Saleem MZ, Ali S, Anwar KK, Bashir MM, Babar M, khan MA. Evaluation of hepatotoxicity of carbon tetrachloride and pharmacological intervention by vitamin $E$ in balb C mice. Pakistan J Zoo. 2019;51(2):755-61.

17. Ritesh KR, Suganya A, Dileepkumar HV, Rajashekar Y, Shivanandappa T. A single acute hepatotoxic dose of $\mathrm{CCl}_{4}$ causes oxidative stress in the rat brain. Toxicol rep. 2015;2:891-95. https://doi.org/10.1016/j.toxrep.2015.05.012.

18. Benahmed F, Rached W, Kerroum F, El Belhouari HFZ. Protective effect of Pistacia atlantica Desf leaves on Mercury-Induced toxicity in Rats. South Asian Journal of Experimental Biology. 2020;10(3):152-161.

19. Zira A, Kostidis S, Theocharis S, Sigala F, Engelsen SB, Andreadou I, Mikros E. 1H NMRbased metabonomics approach in a rat model of acute liver injury and regeneration induced by $\mathrm{CCl}_{4}$ administration. Toxicology. 2013;303:115-124.
20. Hamid A. Diphenyl dimethyl bicarboxylate as an effective treatment for chemical induced fatty liver in rats. Afr J biomed Res. 2006;9:77-81.

21. Lin LF, Doherty DH, Lile JD, Bektesh S, Collins F. GDNF: a glial cell line-derived neurotrophic factor for midbrain dopaminergic neurons. Science. 1993;260(5111):1130-32.

DOI: 10.1126/science.8493557.

22. Zhang WY, Hu XF, Wan N, Zhang JF, Yang $P$, Wen $Q$, Shu YW. Protective effect of the glucagonlike peptide-1 analogue liraglutide on carbon tetrachloride-induced acute liver injury in mice. Biochemical and biophysical research communications, 2019;514(2):386-392.

23. Bhattacharjee R. Effect of vitamin $E$ aerosol on antioxidant imbalance in idiopathic pulmonary fibrosis. Lancet. 2006;338:215-16.

24. Anthea M, Hopkins J, William C, Laughlin MC, Johnson S, Warner M, LaHart D, Wright J. Human biology and health. 1st ed. New Jersey, USA: Englewood Cliffs Publishing; 1993. pp. 52-59.

25. Afzal M, Kazmi I, Kaur R, Ahmad A, Pravez M, Anwar F. Comparison of protective and curative potential of Daucus carota root extract on renal ischemia reperfusion injury in rats. Pharmaceutical biology. 2013;51(7):856-862.

26. Kula J, Izydorczyk K, Czajkowska A, Bonikowski R. Chemical composition of carrot umbel oils from Daucus carota L. ssp. sativus cultivated in Poland. Flavour and fragrance journal. 2006;21(4):667669. https://doi.org/10.1002/ffj.1646.

27. Shebaby WN, Daher CF, El-Sibai M, BodmanSmith K, Mansour A, Karam MC, Mroueh M. Antioxidant and hepatoprotective activities of the oil fractions from wild carrot (Daucus carota ssp. carota). Pharmaceutical biology. 2015;53(9):12851294. https://doi.org/10.3109/13880209.2014.976349.

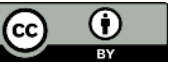

This is an Open Access article distributed under the terms of the Creative Commons Attribution License (http://creativecommons.org/licenses/by/4.0), which permits unrestricted use, distribution, and reproduction in any medium, provided the original work is properly cited. 